\title{
Loss of Weight Gained During the COVID-19 Pandemic: Content Analysis of YouTube Videos
}

Hao Tang ${ }^{1}$, MS; Sungwoo Kim², MS; Priscila E Laforet ${ }^{3}$, MPH; Naa-Solo Tettey ${ }^{4}$, MPH, EdD; Corey H Basch ${ }^{4}$, $\mathrm{MPH}, \mathrm{EdD}$

\footnotetext{
${ }^{1}$ Department of Health and Behavior Studies, Teachers College, Columbia University, New York, NY, United States

${ }^{2}$ Department of Human Development, Teachers College, Columbia University, New York, NY, United States

${ }^{3}$ Mailman School of Public Health, Columbia University, New York, NY, United States

${ }^{4}$ Department of Public Health, William Paterson University, Wayne, NJ, United States
}

\section{Corresponding Author:}

Hao Tang, MS

Department of Health and Behavior Studies

Teachers College

Columbia University

528 West 121st Street

New York, NY, 10027

United States

Phone: 12126783964

Email: ht2489@tc.columbia.edu

\section{Abstract}

Background: Many people experienced unintended weight gain during the COVID-19 pandemic, which has been discussed widely on social media.

Objective: This study aims to describe the content of weight loss videos on YouTube (Google LLC) during the COVID-19 pandemic.

Methods: By using the keywords weight loss during quarantine, the 100 most viewed English-language videos were identified and coded for content related to losing weight gained during the COVID-19 pandemic.

Results: In total, 9 videos were excluded due to having non-English content or posting data before the COVID-19 pandemic. The 91 videos included in the study sample acquired 407,326 views at the time of study and were roughly 14 minutes long. A total of $48 \%$ (44/91) of the sample videos included graphic comparisons to illustrate weight change. Videos that included a graphic comparison were more likely to have content related to trigger warnings $\left(\chi_{1}^{2}=6.05 ; P=.01\right)$, weight loss $\left(\chi_{1}^{2}=13.39 ; P<.001\right)$, negative feelings during quarantine $\left(\chi_{1}^{2}=4.75 ; P=.03\right)$, instructions for losing weight $\left(\chi_{1}^{2}=9.17 ; P=.002\right)$, self-love $\left(\chi_{1}^{2}=6.01\right.$; $P=.01)$, body shaming $\left(\chi_{1}^{2}=4.36 ; P=.04\right)$, and special dietary practices $\left(\chi_{1}^{2}=11.10 ; P<.001\right)$ but were less likely to include food recipes $\left(\chi_{1}^{2}=5.05 ; P=.03\right)$. Our regression analysis results suggested that mentioning quarantine $(P=.05)$, fat-gaining food $(P=.04)$, self-care and self-love $(P=.05)$, and body shaming $(P=.008)$ and having presenters from both sexes $(P<.001)$ are significant predictors for a higher number of views. Our adjusted regression model suggested that videos with content about routine change have significantly lower view counts $(P=.03)$ than those of videos without such content.

Conclusions: The findings of this study indicate the ways in which YouTube is being used to showcase COVID-19-related weight loss in a pre-post fashion. The use of graphic comparisons garnered a great deal of attention. Additional studies are needed to understand the role of graphic comparisons in social media posts. Further studies that focus on people's attitudes and behaviors toward weight change during the COVID-19 pandemic and the implications of social media on these attitudes and behaviors are warranted.

(JMIR Form Res 2022;6(2):e35164) doi: 10.2196/35164

\section{KEYWORDS}

COVID-19; quarantine; weight loss; weight gain; social media; YouTube 


\section{Introduction}

COVID-19 is a contagious respiratory illness caused by the novel coronavirus (SARS-CoV-2). The World Health Organization declared the COVID-19 outbreak a global pandemic due to its rapid spread and alarming severity in March 2020 [1]. In an early attempt to reduce the transmission of SARS-CoV-2 (ie, to "flatten the curve") [2], over 100 countries have implemented self-quarantine at different points since January 2020 (referred to as lockdown) [2,3]. In March 2020, different regions in the United States enforced lockdowns of varying stringency, with most regions restricting outdoor activities and shutting down schools and other nonessential businesses [4,5]. Some states announced stay-at-home orders with a mandate that all nonessential work was to be conducted from home [4]. After the COVID-19 vaccines became available to the general public in December 2020, businesses gradually reopened, but social distancing was largely still encouraged [6]. The unprecedented shutdown has effectively slowed the spread of COVID-19 and averted an estimated 531 million coronavirus infections around the world, including 60 million infections in the United States [7]. Despite this however, the negative consequences of the COVID-19 pandemic persist. These include job losses [8] and the increased prevalence of mental health issues (eg, depression and anxiety) [9,10], as well as a myriad of additional societal losses [11]. The COVID-19 quarantine has also resulted in significant lifestyle changes, such as variations to customary eating habits and physical activity $[12,13]$. These changes have resulted in widespread concerns about weight gain and body image [14]. Reflecting this, the term quarantine 15 is highly discussed on social media $[15,16]$. For example, a recent search yielded approximately 50,600 videos on YouTube (Google LLC) that include quarantine 15 in their titles. Further, a cursory search of the term quarantine 15 yielded more than 619,000 Instagram posts, not including thousands of posts using related terms and those found in other social media outlets, such as Twitter and Facebook.

Social media has long been a popular tool for sharing and disseminating prompt, health-related information and a cost-effective information and education platform that can help with intervening in health behaviors [17], including weight management. For example, weight loss is one of the most searched topics on the internet [17]. However, not all social media use is positive, especially when it comes to promoting health behaviors such as safe and effective weight loss. For example, content that stigmatizes weight gain or triggers eating disorders is present on social media [16,18]. Moreover, recent evidence suggests that image-centric social media platforms have a greater impact on body image dissatisfaction and eating disorder behaviors than non-image-centric social media platforms [19]. As one of the most popular video-sharing platforms around the globe [20-22], YouTube has been the focal point of a range of studies related to COVID-19. Given the widespread concerns about undesired weight gain, the popularity of YouTube, and the long-existing risk of social media content $[14,16,17]$, it is important to characterize the trending weight-related social media posts during the COVID-19 quarantine to investigate the effect of quarantine on individuals' behaviors and health [16]. Therefore, the purpose of this study was to describe the content of weight loss videos on YouTube during the COVID-19 pandemic.

\section{Methods}

This was a qualitative, content analysis study that adapted methods from prior studies that analyzed YouTube videos on COVID-19 vaccination [23,24]. By using "visitor" mode, we conducted searches with the keywords quarantine weight loss and quarantine weight gain and found that the results were similar. To keep the view count as a valid measure, we used 1 key term-quarantine weight loss - to filter the first 100 videos by view count. However, 6 of the most viewed videos were not presented in English, and 3 videos were posted before the pandemic (ie, before 2019). As such, only 91 videos were coded and analyzed.

A total of 23 coding categories were used to code each video, and only 7 basic information categories [25], including (1) URL, (2) upload date, (3) view count, (4) thumbs-up, (5) thumbs-down, (6) video length (in minutes and seconds), and (7) presenter sex, were coded and recorded on the same day. Thumbs-up and thumbs-down counts were subsequently used to calculate the like to dislike ratio. Additional categories were extracted from related articles, a World Health Organization report, and the first 10 most viewed videos [14,25-27]. These characteristic categories were (1) including a trigger warning or disclaimer, (2) mentioning quarantine, (3) including a graphic comparison of pre- and post-pandemic weight (cover, picture, or video), (4) mentioning weight gain during quarantine, (5) mentioning an exact amount of quarantine weight gain, (6) mentioning weight loss during quarantine, (7) mentioning an exact amount of quarantine weight loss, (8) mentioning personal causes of quarantine weight gain, (9) mentioning negative feelings during quarantine, (10) highlighting food of low nutritional quality (dessert or ultraprocessed food), (11) mentioning exercise, (12) mentioning how to lose weight during quarantine, (13) highlighting weight loss pills or products, (14) mentioning self-love or self-care, (15) mentioning body shaming, (16) mentioning a specific diet, and (17) including recipes.

Each video was coded as "1" (yes) or " 0 " (no) for whether the video mentioned these characteristic categories. Means, SDs, and ranges were calculated for the view count, thumbs-up, thumbs-down, and video length variables. Frequencies and percentages were calculated for all categorical variables. Chi-square tests were used to investigate associations between the inclusion of a graphic comparison of pre- and postpandemic weight and other video characteristics. In addition, a correlation analysis was conducted to determine if there were significant relationships among various video characteristics. Finally, a regression analysis was conducted, with view count (in thousands) as a dependent variable and different video characteristics as independent variables, to test for significant predictors of higher view counts. After the initial interpretation of results, a stepwise regression was performed to reduce the complexity of our model and produce a more efficient model. The descriptive analyses (correlation and chi-square tests) were 
performed by using SPSS version 27 (IBM Corporation), and the regression analysis with subset selection was conducted with RStudio 1.4.1717. This study was not reviewed by the institutional review boards of Columbia University and William Paterson University because it did not involve human subjects, per their policies.

\section{Results}

The 91 YouTube videos on weight loss during quarantine had an average of 407,326 views; this value had a high SD of
836,478 views. Most $(65 / 91,71 \%)$ of the videos were uploaded between January 1 and August 2, 2020, and only 29\% (26/91) of videos were uploaded between August 2, 2020, and March 2,2021 . The majority of videos were presented by females $(65 / 91,71 \%)$. The videos were roughly 14 minutes long on average, though the length ranged from 2 minutes to 1 hour. Most videos were very positively rated; the average like to dislike ratio was $98 \%$. A complete list of the characteristics included in these videos is outlined in Table 1. 
Table 1. Characteristics of the most viewed YouTube videos on quarantine weight loss ( $\mathrm{N}=91)$.

\begin{tabular}{ll}
\hline Characteristics & Values \\
\hline Upload date of videos, $\mathbf{n}(\boldsymbol{\%})$ & $65(71)$ \\
$\quad$ Between January 1 and August 2, 2020 & $26(29)$ \\
$\quad$ Between August 2, 2020, and March 2, 2021 & $407,326,69(836,478.02 ; 44,181-5,396,499)$ \\
View count, mean (SD; range) & $13,004.82(24,237.7 ; 639-176,000)$ \\
Thumbs-up (like) count, mean (SD; range) & $203.31(297.4 ; 16-1500)$ \\
Thumbs-down (dislike) count, mean (SD; range) & $847.19(614.8 ; 141-4063)$ \\
Video length (seconds), mean (SD; range) & \\
Presenter sex, $\mathbf{n}(\%)$ & $65(71)$ \\
Female & $22(24)$ \\
Male & $4(4)$ \\
Both & \\
Includes a trigger warning or disclaimer, $\mathbf{n}(\boldsymbol{\%})$ & $14(15)$ \\
Yes & $77(85)$ \\
No & $83(91)$ \\
Mentions quarantine, $\mathbf{n}(\boldsymbol{\%})$ & $8(9)$ \\
Yes &
\end{tabular}

Includes a graphic comparison of pre- and postpandemic weight (cover, picture, or video), $\mathbf{n}(\%)$

Yes

No

Mentions the exact amount of quarantine weight gain, $\mathbf{n}(\%)$

Yes

No

Mentions the exact amount of quarantine weight loss, $\mathbf{n}(\%)$

Yes

No

Mentions weight gain during quarantine, $\mathrm{n}(\%)$

Yes

No

Mentions weight loss during quarantine, $\mathbf{n}(\%)$

Yes

No

Mentions personal causes of quarantine weight gain, $\mathbf{n}(\%)$

Yes

No

Mentions negative feelings during quarantine, $n(\%)$

Yes

No

Highlights fat-gaining food (dessert or ultraprocessed food), $\mathbf{n}(\%)$

Yes

No

Mentions exercise, $\mathbf{n}(\%)$ 


\begin{tabular}{|c|c|}
\hline Characteristics & Values \\
\hline Yes & $62(68)$ \\
\hline No & $29(32)$ \\
\hline \multicolumn{2}{|c|}{ Mentions how to lose weight during quarantine, $n(\%)$} \\
\hline Yes & $38(42)$ \\
\hline No & $53(58)$ \\
\hline \multicolumn{2}{|c|}{ Highlights weight loss pills or products, $n$ (\%) } \\
\hline Yes & $24(26)$ \\
\hline No & $67(74)$ \\
\hline \multicolumn{2}{|c|}{ Mentions self-love or self-care, $n(\%)$} \\
\hline Yes & $30(33)$ \\
\hline No & $61(67)$ \\
\hline \multicolumn{2}{|c|}{ Mentions body shaming, $\mathrm{n}(\%)$} \\
\hline Yes & $10(11)$ \\
\hline No & $81(89)$ \\
\hline \multicolumn{2}{|c|}{ Mentions a specific diet, $n(\%)$} \\
\hline Yes & $27(30)$ \\
\hline No & $64(70)$ \\
\hline \multicolumn{2}{|c|}{ Includes recipes, $\mathbf{n}(\%)$} \\
\hline Yes & $33(36)$ \\
\hline No & $58(64)$ \\
\hline
\end{tabular}

Table 2 features a compilation of chi-square tests of independence for testing the relationship between the inclusion of a graphic pre-post weight comparison and various other video characteristics. Videos that included a trigger warning were more likely to feature a graphic comparison $\left(\chi_{1}^{2}=6.05 ; P=.01\right)$. Such videos that included a graphic comparison of pre- and postpandemic weight also mentioned weight loss more often than videos without a graphic comparison $\left(\chi_{1}^{2}=13.39 ; P<.001\right)$ and more often mentioned negative feelings during quarantine $\left(\chi_{1}^{2}=4.75 ; P=.03\right)$. In addition, videos with a graphic comparison more frequently included how-to instructions $\left(\chi_{1}^{2}=9.17 ; P=.002\right)$ and more frequently mentioned self-love $\left(\chi_{1}^{2}=6.01 ; P=.01\right)$, body shaming $\left(\chi_{1}^{2}=4.36 ; P=.04\right)$, and special dietary practices $\left(\chi_{1}^{2}=11.10 ; P<.001\right)$. However, videos with graphic comparisons significantly less often included food recipes $\left(\chi_{1}^{2}=5.05 ; P=.03\right)$. 
Table 2. Associations between the inclusion of a graphic comparison of pre- and postpandemic weight and video characteristics.

\begin{tabular}{|c|c|c|c|c|c|}
\hline \multirow[t]{2}{*}{ Categories } & \multicolumn{3}{|c|}{ Includes a graphic comparison } & \multirow[t]{2}{*}{ Chi-square $(d f)$} & \multirow[t]{2}{*}{$P$ value } \\
\hline & No, $\mathrm{n}$ & Yes, $\mathrm{n}$ & Total, $\mathrm{N}$ & & \\
\hline Presenter sex & 47 & 44 & 91 & $0.47(2)$ & .79 \\
\hline Female & 35 & 30 & 65 & & \\
\hline Male & 10 & 12 & 22 & & \\
\hline Both & 2 & 2 & 4 & & \\
\hline Includes a trigger warning or disclaimer & 47 & 44 & 91 & $6.05(1)$ & $.01^{\mathrm{a}}$ \\
\hline No & 44 & 33 & 77 & & \\
\hline Yes & 3 & 11 & 14 & & \\
\hline Mentions quarantine & 47 & 44 & 91 & $0.01(1)$ & .92 \\
\hline No & 4 & 4 & 8 & & \\
\hline Yes & 43 & 40 & 83 & & \\
\hline Mentions weight gain & 47 & 44 & 91 & $0.79(1)$ & .37 \\
\hline No & 34 & 28 & 62 & & \\
\hline Yes & 13 & 16 & 29 & & \\
\hline Mentions weight loss & 47 & 44 & 91 & $13.39(1)$ & $<.001^{\mathrm{a}}$ \\
\hline No & 26 & 8 & 34 & & \\
\hline Yes & 21 & 36 & 57 & & \\
\hline Includes a COVID-19 weight change-related term & 47 & 43 & 90 & $9.56(1)$ & $.002^{\mathrm{a}}$ \\
\hline No & 45 & 31 & 76 & & \\
\hline Yes & 2 & 12 & 14 & & \\
\hline Mentions weight gain cause & 47 & 44 & 91 & $0.92(1)$ & .34 \\
\hline No & 40 & 34 & 74 & & \\
\hline Yes & 7 & 10 & 17 & & \\
\hline Mentions negative feelings during quarantine & 47 & 44 & 91 & $4.75(1)$ & $.03^{\mathrm{a}}$ \\
\hline No & 32 & 20 & 52 & & \\
\hline Yes & 15 & 24 & 39 & & \\
\hline Mentions fat-gaining food & 47 & 44 & 91 & $2.24(1)$ & .14 \\
\hline No & 41 & 33 & 74 & & \\
\hline Yes & 6 & 11 & 17 & & \\
\hline Mentions exercise & 47 & 44 & 91 & $3.28(1)$ & .07 \\
\hline No & 19 & 10 & 29 & & \\
\hline Yes & 28 & 34 & 62 & & \\
\hline Mentions routine or life change & 47 & 44 & 91 & $0.07(1)$ & .79 \\
\hline No & 19 & 19 & 38 & & \\
\hline Yes & 28 & 25 & 53 & & \\
\hline Mentions how to lose weight & 47 & 44 & 91 & $9.17(1)$ & $.002^{\mathrm{a}}$ \\
\hline No & 34 & 18 & 52 & & \\
\hline Yes & 13 & 26 & 39 & & \\
\hline Highlights weight loss pills or products & 47 & 44 & 91 & $0.04(1)$ & .85 \\
\hline No & 35 & 32 & 67 & & \\
\hline
\end{tabular}




\begin{tabular}{|c|c|c|c|c|c|}
\hline \multirow[t]{2}{*}{ Categories } & \multicolumn{3}{|c|}{ Includes a graphic comparison } & \multirow[t]{2}{*}{ Chi-square $(d f)$} & \multirow[t]{2}{*}{$P$ value } \\
\hline & No, $n$ & Yes, $\mathrm{n}$ & Total, N & & \\
\hline Yes & 12 & 12 & 24 & & \\
\hline Mentions self-love or self-care & 47 & 44 & 91 & $6.01(1)$ & $.01^{\mathrm{a}}$ \\
\hline No & 37 & 24 & 61 & & \\
\hline Yes & 10 & 20 & 30 & & \\
\hline Mentions body shaming & 47 & 44 & 91 & $4.51(1)$ & $.03^{\mathrm{a}}$ \\
\hline No & 45 & 36 & 81 & & \\
\hline Yes & 2 & 8 & 10 & & \\
\hline Mentions a specific diet (eg, keto diet, etc) & 47 & 44 & 91 & $10.17(1)$ & $.001^{\mathrm{a}}$ \\
\hline No & 40 & 24 & 64 & & \\
\hline Yes & 7 & 20 & 27 & & \\
\hline Includes recipes & 47 & 44 & 91 & $3.68(1)$ & $.03^{\mathrm{a}}$ \\
\hline No & 25 & 33 & 58 & & \\
\hline Yes & 22 & 11 & 33 & & \\
\hline
\end{tabular}

${ }^{\mathrm{a}}$ Statistically significant at a $P<.05$ significance level.

A regression analysis with a full list of 21 factors was conducted to create a statistically significant $\operatorname{model}\left(F_{21,68}=3.223 ; P<.001\right)$ with moderate model fit $\left(R^{2}=34.4 \%\right)$. Videos that mentioned COVID-19 quarantine had approximately 580,000 more views than those that did not mention COVID-19 quarantine $(P=.05)$. In addition, talking about fat-gaining food $(P=.04)$, self-love

$(P=.05)$, and body shaming $(P=.008)$ significantly contributed to higher view counts. Further, videos with both male and female presenters had, on average, 1.8 million more views than videos with male presenters and 1.5 million more views compared to videos with female presenters $(P<.001)$. Table 3 outlines the full list of regression coefficients. 
Table 3. Regression analysis with full factors.

\begin{tabular}{|c|c|c|c|}
\hline Characteristics & $\mathrm{B}(\mathrm{SE})$ & $t$ test $(d f)^{\mathrm{a}}$ & $P$ value \\
\hline Intercept & $-3420.035(2411.484)$ & $-1.418(68)$ & .16 \\
\hline Like to dislike ratio & $3537.054(2449.459)$ & $1.444(68)$ & .15 \\
\hline Length (seconds) & $-0.241(0.141)$ & $-1.714(68)$ & .09 \\
\hline Includes a trigger warning & $278.817(236.567)$ & $1.179(68)$ & .24 \\
\hline Mentions quarantine & $580.534(290.706)$ & $1.997(68)$ & $.05^{\mathrm{b}}$ \\
\hline Mentions a graphic comparison & $-17.898(205.592)$ & $-0.087(68)$ & .93 \\
\hline Mentions weight gain & $-111.256(205.264)$ & $-0.542(68)$ & .59 \\
\hline Mentions weight loss & $-295.420(174.849)$ & $-1.690(68)$ & .10 \\
\hline Includes a COVID-19 weight change-related term & $-217.298(229.365)$ & $-0.947(68)$ & .35 \\
\hline Mentions weight gain cause & $-535.506(264.648)$ & $-2.023(68)$ & $.047^{\mathrm{b}}$ \\
\hline Mentions negative feelings & $128.832(188.775)$ & $0.682(68)$ & .50 \\
\hline Mentions fat-gaining food & $470.720(218.611)$ & $2.153(68)$ & $.04^{\mathrm{b}}$ \\
\hline Mentions exercise & $28.272(176.027)$ & $0.161(68)$ & .87 \\
\hline Mentions a routine or life change & $-392.194(209.015)$ & $-1.876(68)$ & .07 \\
\hline Mentions how to lose weight & $350.152(182.994)$ & $1.913(68)$ & .06 \\
\hline Highlights weight loss pills or products & $16.195(190.823)$ & $0.085(68)$ & .93 \\
\hline Mentions self-love or self-care & $389.582(195.430)$ & $1.993(68)$ & $.05^{\mathrm{b}}$ \\
\hline Mentions body shaming & $700.194(255.749)$ & $2.738(68)$ & $.008^{\mathrm{c}}$ \\
\hline Mentions a specific diet (eg, keto, etc) & $-56.951(198.153)$ & $-0.287(68)$ & .78 \\
\hline Includes recipes & $-113.440(179.326)$ & $-0.633(68)$ & .53 \\
\hline Presenter is female & $269.498(187.232)$ & $1.439(68)$ & .16 \\
\hline Includes both male and female presenters & $1848.469(394.523)$ & $4.685(68)$ & $<.001^{\mathrm{c}}$ \\
\hline
\end{tabular}

${ }^{\mathrm{a}}$ Values are from a regression analysis.

${ }^{\mathrm{b}}$ Statistically significant at a $P<.05$ level.

${ }^{\mathrm{c}}$ Statistically significant at a $P<.01$ level.

To reduce the number of parameters and improve model fit, forward and backward stepwise regressions were performed. Among the two models, the backward stepwise regression model was selected because it had a lower Akaike Information Criteria value (1195.92) compared to that of the forward regression model (1208.15). The selected model was, overall, significantly similar to the full model $\left(F_{11,79}=5.506 ; P<.001\right)$ and had a

slightly improved model fit $\left(R^{2}=35.5 \%\right)$. The reduced model included 11 out of the 21 variables, and the complete list of the coefficients can be found in Table 4 . The effects of mentioning quarantine $(P=.049)$ and body shaming $(P=.009)$ and presenter sex $(P<.001)$ stayed significant. In addition, mentioning changes in life routine was selected as a significant predictor of view count $(P=.03)$, though videos that included content about routine change had approximately 380,000 fewer views. 
Table 4. Backward stepwise regression analysis with reduced variables ${ }^{\mathrm{a}}$.

\begin{tabular}{llll}
\hline Characteristics & B (SE) & $t$ test $(d f)^{\mathrm{b}}$ & \multicolumn{1}{c}{$P$ value } \\
\hline Intercept & $-3323.7(2291.4)$ & $-1.451(79)$ & .15 \\
Like to dislike ratio & $3329.7(2304.5)$ & $1.445(79)$ & .15 \\
Length (seconds) & $-0.2(0.1)$ & $1.997(79)$ & .08 \\
Mentions quarantine & $556.1(278.4)$ & $-1.626(79)$ & $.049^{\mathrm{c}}$ \\
Mentions weight gain & $-271.6(167.1)$ & $1.778(79)$ & .11 \\
Highlights fat-gaining food & $342.1(192.4)$ & $-2.212(79)$ & .08 \\
Mentions a routine or life change & $-385.6(173.4)$ & $1.889(79)$ & $.03^{\mathrm{c}}$ \\
Mentions how to lose weight & $296.8(157.1)$ & $1.339(79)$ & .06 \\
Mentions self-love or self-care & $221.5(165.5)$ & $2.660(79)$ & .18 \\
Mentions body shaming & $630.9(237.1)$ & $1.432(79)$ & $.009^{\mathrm{d}}$ \\
Presenter is female & $246.0(171.9)$ & $5.100(79)$ & .16 \\
Includes both male and female presenters & $1889.4(369.1)$ & $<.001^{\mathrm{d}}$ \\
\hline
\end{tabular}

${ }^{\mathrm{a}}$ The Akaike Information Criteria and Bayesian Information Criteria values of the model were 1195.92 and 1195.92, respectively.

${ }^{\mathrm{b}}$ Values are from a regression analysis.

${ }^{\mathrm{c}}$ Statistically significant at a $P<.05$ level.

${ }^{\mathrm{d}}$ Statistically significant at a $P<.01$ level.

\section{Discussion}

The findings of this study are important in that they indicate the ways in which YouTube is being used to showcase weight loss in a pre-post fashion. Further, videos that used graphic comparisons garnered the most attention and included less of the studied content compared to those that did not use such comparisons. The power of graphic depiction has long been recognized in many fields, including research, education, and business [28-30]. One example is the social comparison theory, which posits that self-worth is often determined through the assessment of differences and similarities with others [31]. This highlights why exposure to body images on social media can result in both positive and negative consequences [32,33].

Many studies have found that social media posts with pictures usually induce higher levels of engagement with eating disorder behaviors than those induced by posts without pictures [34,35]. In this study, videos that included a graphic comparison of preand postpandemic weight usually talked about weight loss (mentions weight loss, mentions how to lose weight, and mentions the exact amount of quarantine weight loss) but not weight gain. It is possible that weight loss has always been a popular topic in social media [36]. As such, video makers wanted to make their video content stand out by showing the efficacy of their weight loss journeys with graphic comparisons.

On the other hand, it should be noted that graphic posts can magnify the risk of social media use with regard to body objectification, body dissatisfaction, and eating disorders [19,37-40]. Graphic comparison is a strategy that is used to motivate participants by demonstrating the potential results of following a suggested regimen or advice. However, instead of promoting body positivity, some graphic comparisons have the opposite effect because they are based on the erroneous belief that fat shaming or weight stigma can serve as a motivator for weight loss [41,42]. Transformational graphic images often focus on decreased size and high amounts of weight loss as determinants of good health. The linking of weight to health can lead to negative body image and decreased self-esteem for those who do not meet the criteria in the posted images or videos [43]. In addition, this strategy does not often lead to motivation but instead can discourage and decrease the self-efficacy of viewers who do not believe that they can achieve the weight loss goals portrayed in such images or videos [43]. Furthermore, considering racial and ethnic representation and cultural body image standards within these images is important for reaching a diverse audience and achieving body inclusivity [44].

Including trigger warnings could be an effective strategy for limiting exposure to content that can distort body image. We found that videos that include a pre-post graphic comparison are more likely to include trigger warnings or disclaimers and mention self-love, self-care, and body shaming compared to those without a graphic comparison. Only $15 \%$ (14/91) of these popular videos discussing weight change included trigger warnings or disclaimers. Social media platforms and content creators should be more aware of the potential risk of content related to body image and promote policies to reduce this risk. Future studies should seek to develop best practices for developing graphic images in a way that promotes health and body positivity instead of just weight loss and a thin body ideal.

The literature indicates that several lifestyle changes during the COVID-19 quarantine have resulted in weight gain and increased the risk for obesity $[45,46]$, which is a primary public health concern $[47,48]$. Studies have confirmed that weight gain was commonplace around the globe during the COVID-19 quarantine $[14,45,46,49]$. The interruption of usual routines and 
restriction of social behaviors due to the COVID-19 quarantine can result in increased boredom [12] and stress [50], which in turn induce emotional eating and food craving [51-53]. Additionally, higher energy intake; the higher consumption of sugar, fat, and alcohol; and the limited availability of fresh fruits and vegetables $[13,54]$ during quarantine increased the risk for overweight and many metabolic diseases [55]. In addition, the decrease in physical activity and increase in sedentary behaviors, such as screen time, during the COVID-19 quarantine may also contribute to weight and fat gain [56].

This study is limited by its cross-sectional design, the sole inclusion of English-language videos, and the search term being limited to 1 phrase. There is no indication of how our results may have differed at other points in time during the pandemic, as quarantine rules varied greatly over time. Despite these limitations, this study does contribute to a gap in the literature and may encourage researchers to conduct studies related to the loss of weight gained during the COVID-19 pandemic.

Social media use increased significantly during the COVID-19 pandemic, since it has helped people feel connected with others and has kept them updated with news and entertained while staying at home [16,57]. More than half of US adults reported the increased use of social media platforms after the pandemic [58]. Social media sites like YouTube provide an opportunity for lay content creators, as well as public health organizations, to reach large audiences and provide content that can promote improved body image and increased focus on health rather than weight [59]. The lessons learned from the COVID-19 pandemic should serve as a catalyst for public health practitioners to develop evidence-based tools that people can use to remain healthy should an extended quarantine occur again. Many creators of social media content that focuses on weight loss are not trained in health education or public health and may not be using evidence-based strategies to develop content. It would be beneficial for trusted organizations to develop evidence-based social media education and training with guidelines for maintaining a healthy weight and establishing healthy behaviors during times of quarantine or other public health emergencies. Further studies that focus on people's attitudes and behaviors toward weight change during the COVID-19 pandemic and the implications of social media on these attitudes and behaviors are warranted.

\section{Authors' Contributions}

CHB and HT conceptualized the study. HT collected the data. SK and PEL conducted the data analysis. All authors contributed to manuscript production.

\section{Conflicts of Interest}

None declared.

\section{References}

1. Cucinotta D, Vanelli M. WHO declares COVID-19 a pandemic. Acta Biomed 2020 Mar 19;91(1):157-160 [FREE Full text] [doi: 10.23750/abm.v91i1.9397] [Medline: 32191675]

2. Perra N. Non-pharmaceutical interventions during the COVID-19 pandemic: A review. Phys Rep 2021 May 23;913:1-52 [FREE Full text] [doi: 10.1016/j.physrep.2021.02.001] [Medline: $\underline{33612922}$ ]

3. Levenson M. Scale of China's Wuhan shutdown is believed to be without precedent. The New York Times. 2020 Jan 22. URL: https://www.nytimes.com/2020/01/22/world/asia/coronavirus-quarantines-history.html [accessed 2021-08-10]

4. Chappell B, Romo V. New York, Illinois governors issue stay at home orders, following California's lead. National Public Radio. 2020 Mar 20. URL: https://www.npr.org/sections/coronavirus-live-updates/2020/03/20/818952589/ coronavirus-n-y-gov-cuomo-says-100-of-workforce-must-stay-home [accessed 2022-01-11]

5. Ravani S. Bay Area coronavirus decision: Behind the scenes of nation's first shelter-in-place order. San Francisco Chronicle. 2020 Mar 21. URL: https://www.sfchronicle.com/bayarea/article/

Bay-Area-coronavirus-decision-Behind-the-scenes-15148425.php [accessed 2022-01-11]

6. COVID-19 restrictions. Map of COVID-19 case trends and restrictions. USA Today. URL: https://www.usatoday.com/ storytelling/coronavirus-reopening-america-map/ [accessed 2021-08-19]

7. Hsiang S, Allen D, Annan-Phan S, Bell K, Bolliger I, Chong T, et al. The effect of large-scale anti-contagion policies on the COVID-19 pandemic. Nature 2020 Aug;584(7820):262-267. [doi: 10.1038/s41586-020-2404-8] [Medline: 32512578]

8. Unemployment rates during the COVID-19 pandemic. Congressional Research Service. 2021. URL: https://fas.org/sgp/ crs/misc/R46554.pdf [accessed 2021-08-19]

9. Schippers MC. For the greater good? The devastating ripple effects of the Covid-19 crisis. Front Psychol 2020 Sep 29;11:577740 [FREE Full text] [doi: 10.3389/fpsyg.2020.577740] [Medline: 33132987 ]

10. Holmes EA, O'Connor RC, Perry VH, Tracey I, Wessely S, Arseneault L, et al. Multidisciplinary research priorities for the COVID-19 pandemic: a call for action for mental health science. Lancet Psychiatry 2020 Jun;7(6):547-560 [FREE Full text] [doi: 10.1016/S2215-0366(20)30168-1] [Medline: 32304649]

11. Lopez-Leon S, Wegman-Ostrosky T, Perelman C, Sepulveda R, Rebolledo PA, Cuapio A, et al. More than 50 long-term effects of COVID-19: a systematic review and meta-analysis. Sci Rep 2021 Aug 09;11(1):16144 [FREE Full text] [doi: 10.1038/s41598-021-95565-8] [Medline: $\underline{\text { 34373540] }}$ 
12. Di Renzo L, Gualtieri P, Pivari F, Soldati L, Attinà A, Cinelli G, et al. Eating habits and lifestyle changes during COVID-19 lockdown: an Italian survey. J Transl Med 2020 Jun 08;18(1):229 [FREE Full text] [doi: 10.1186/s12967-020-02399-5] [Medline: 32513197]

13. Bennett G, Young E, Butler I, Coe S. The impact of lockdown during the COVID-19 outbreak on dietary habits in various population groups: A scoping review. Front Nutr 2021 Mar 04;8:626432 [FREE Full text] [doi: 10.3389/fnut.2021.626432] [Medline: 33748175]

14. Jordan AK, Barnhart WR, Studer-Perez EI, Kalantzis MA, Hamilton L, Musher-Eizenman DR. 'Quarantine 15': Pre-registered findings on stress and concern about weight gain before/during COVID-19 in relation to caregivers' eating pathology. Appetite 2021 Nov 01;166:105580. [doi: 10.1016/j.appet.2021.105580] [Medline: 34186158]

15. Keel PK, Gomez MM, Harris L, Kennedy GA, Ribeiro J, Joiner TE. Gaining "The Quarantine 15:" Perceived versus observed weight changes in college students in the wake of COVID-19. Int J Eat Disord 2020 Nov;53(11):1801-1808 [FREE Full text] [doi: 10.1002/eat.23375] [Medline: 32856752]

16. Pearl RL. Weight stigma and the "Quarantine-15". Obesity (Silver Spring) 2020 Jul;28(7):1180-1181 [FREE Full text] [doi: 10.1002/oby.22850] [Medline: 32324954]

17. Jane M, Hagger M, Foster J, Ho S, Pal S. Social media for health promotion and weight management: a critical debate. BMC Public Health 2018 Jul 28;18(1):932 [FREE Full text] [doi: 10.1186/s12889-018-5837-3] [Medline: 30055592]

18. Das L, Mohan R, Makaya T. The bid to lose weight: impact of social media on weight perceptions, weight control and diabetes. Curr Diabetes Rev 2014;10(5):291-297. [doi: 10.2174/1573399810666141010112542] [Medline: 25311196]

19. Griffiths S, Murray SB, Krug I, McLean SA. The contribution of social media to body dissatisfaction, eating disorder symptoms, and anabolic steroid use among sexual minority men. Cyberpsychol Behav Soc Netw 2018 Mar;21(3):149-156 [FREE Full text] [doi: 10.1089/cyber.2017.0375] [Medline: 29363993]

20. Digital 2021 - Social media marketing and management dashboard. Hootsuite. URL: https://www.hootsuite.com/resources/ digital-trends [accessed 2021-08-10]

21. YouTube: Statistics and facts. Statista. 2021 Jul 12. URL: https://www.statista.com/topics/2019/youtube/ [accessed 2021-08-10]

22. Newberry C. 25 YouTube statistics that may surprise you: 2021 edition. Hootsuite. 2021 Feb 02. URL: https://blog. hootsuite.com/youtube-stats-marketers/ [accessed 2021-08-10]

23. Basch CE, Basch CH, Hillyer GC, Meleo-Erwin ZC, Zagnit EA. YouTube videos and informed decision-making about COVID-19 vaccination: Successive sampling study. JMIR Public Health Surveill 2021 May 06;7(5):e28352 [FREE Full text] [doi: 10.2196/28352] [Medline: 33886487]

24. Basch CH, Hillyer GC, Zagnit EA, Basch CE. YouTube coverage of COVID-19 vaccine development: implications for awareness and uptake. Hum Vaccin Immunother 2020 Nov 01;16(11):2582-2585 [FREE Full text] [doi: $\underline{10.1080 / 21645515.2020 .1790280}$ ] [Medline: $\underline{\text { 32701403] }}$

25. Basch CH, Mohlman J, Fera J, Tang H, Pellicane A, Basch CE. Community mitigation of COVID-19 and portrayal of testing on TikTok: Descriptive study. JMIR Public Health Surveill 2021 Jun 10;7(6):e29528 [FREE Full text] [doi: 10.2196/29528] [Medline: 34081591]

26. Kriaucioniene V, Bagdonaviciene L, Rodríguez-Pérez C, Petkeviciene J. Associations between changes in health behaviours and body weight during the COVID-19 quarantine in Lithuania: The Lithuanian COVIDiet Study. Nutrients 2020 Oct 13;12(10):3119 [FREE Full text] [doi: 10.3390/nu12103119] [Medline: 33065991]

27. Social media and COVID-19: A global study of digital crisis interaction among Gen Z and millennials. World Health Organization. 2021 Dec 01. URL: https://www.who.int/news-room/feature-stories/detail/ social-media-covid-19-a-global-study-of-digital-crisis-interaction-among-gen-Z-and-millennials [accessed 2021-08-10]

28. Dunlap JC, Lowenthal PR. Getting graphic about infographics: design lessons learned from popular infographics. Journal of Visual Literacy 2016 Sep 08;35(1):42-59 [FREE Full text] [doi: 10.1080/1051144x.2016.1205832]

29. Guo D, Zhang S, Wright KL, McTigue EM. Do you get the picture? A meta-analysis of the effect of graphics on reading comprehension. AERA Open 2020 Jan 24;6(1):233285842090169 [FREE Full text] [doi: 10.1177/2332858420901696]

30. Khoury CK, Kisel Y, Kantar M, Barber E, Ricciardi V, Klirs C, et al. Science-graphic art partnerships to increase research impact. Commun Biol 2019 Aug 06;2:295 [FREE Full text] [doi: 10.1038/s42003-019-0516-1] [Medline: 31396575]

31. Festinger L. A theory of social comparison processes. Hum Relat 1954 May 01;7(2):117-140. [doi: $10.1177 / 001872675400700202]$

32. Bennett BL, Whisenhunt BL, Hudson DL, Wagner AF, Latner JD, Stefano EC, et al. Examining the impact of social media on mood and body dissatisfaction using ecological momentary assessment. J Am Coll Health 2020 Jul;68(5):502-508. [doi: 10.1080/07448481.2019.1583236] [Medline: 30908131]

33. Sherlock M, Wagstaff DL. Exploring the relationship between frequency of Instagram use, exposure to idealized images, and psychological well-being in women. Psychol Pop Media Cult 2019;8(4):482-490. [doi: 10.1037/ppm0000182]

34. Newberry C, McLachlan S. Social media advertising 101: How to get the most out of your ad budget. Hootsuite. 2020 Sep 09. URL: https://blog.hootsuite.com/social-media-advertising/ [accessed 2021-09-07]

35. Li Y, Xie Y. Is a picture worth a thousand words? An empirical study of image content and social media engagement. J Mark Res 2019 Nov 18;57(1):1-19 [FREE Full text] [doi: 10.1177/0022243719881113] 
36. Park MB, Wang JM, Bulwer BE. Global dieting trends and seasonality: Social big-data analysis may be a useful tool. Nutrients 2021 Mar 25;13(4):1069 [FREE Full text] [doi: 10.3390/nu13041069] [Medline: $\underline{33806069}$ ]

37. Sidani JE, Shensa A, Hoffman B, Hanmer J, Primack BA. The association between social media use and eating concerns among US young adults. J Acad Nutr Diet 2016 Sep;116(9):1465-1472 [FREE Full text] [doi: 10.1016/j.jand.2016.03.021] [Medline: 27161027]

38. Wilksch SM, O'Shea A, Ho P, Byrne S, Wade TD. The relationship between social media use and disordered eating in young adolescents. Int J Eat Disord 2020 Jan;53(1):96-106. [doi: 10.1002/eat.23198] [Medline: 31797420]

39. Teo NSY, Collinson SL. Instagram and risk of rumination and eating disorders: An Asian perspective. Psychol Pop Media Cult 2019;8(4):491-508. [doi: 10.1037/ppm0000205]

40. Walker M, Thornton L, De Choudhury M, Teevan J, Bulik CM, Levinson CA, et al. Facebook use and disordered eating in college-aged women. J Adolesc Health 2015 Aug;57(2):157-163 [FREE Full text] [doi: 10.1016/j.jadohealth.2015.04.026] [Medline: 26206436]

41. Puhl RM, Heuer CA. Obesity stigma: important considerations for public health. Am J Public Health 2010 Jun;100(6):1019-1028. [doi: 10.2105/AJPH.2009.159491] [Medline: 20075322]

42. Vartanian LR, Pinkus RT, Smyth JM. Experiences of weight stigma in everyday life: Implications for health motivation. Stigma Health 2018;3(2):85-92. [doi: 10.1037/sah0000077]

43. Hunger JM, Major B, Blodorn A, Miller CT. Weighed down by stigma: How weight-based social identity threat contributes to weight gain and poor health. Soc Personal Psychol Compass 2015 Jun;9(6):255-268 [FREE Full text] [doi: 10.1111/spc3.12172] [Medline: 29225670]

44. Lazuka RF, Wick MR, Keel PK, Harriger JA. Are we there yet? Progress in depicting diverse images of beauty in Instagram's body positivity movement. Body Image 2020 Sep;34:85-93. [doi: 10.1016/j.bodyim.2020.05.001] [Medline: $\underline{32534269]}$

45. Zachary Z, Brianna F, Brianna L, Garrett P, Jade W, Alyssa D, et al. Self-quarantine and weight gain related risk factors during the COVID-19 pandemic. Obes Res Clin Pract 2020;14(3):210-216 [FREE Full text] [doi: 10.1016/j.orcp.2020.05.004] [Medline: 32460966]

46. Zeigler Z. COVID-19 self-quarantine and weight gain risk factors in adults. Curr Obes Rep 2021 Sep;10(3):423-433 [FREE Full text] [doi: 10.1007/s13679-021-00449-7] [Medline: $\underline{\text { 34251647] }}$

47. Hales CM, Fryar CD, Carroll MD, Freedman DS, Ogden CL. Trends in obesity and severe obesity prevalence in US youth and adults by sex and age, 2007-2008 to 2015-2016. JAMA 2018 Apr 24;319(16):1723-1725 [FREE Full text] [doi: 10.1001/jama.2018.3060] [Medline: 29570750]

48. Adult obesity facts. Centers for Disease Control and Prevention. URL: https://www.cdc.gov/obesity/data/adult.html [accessed 2021-08-10]

49. One year later, a new wave of pandemic health concerns. American Psychological Association. 2021 Mar 11. URL: https:/ /www.apa.org/news/press/releases/stress/2021/one-year-pandemic-stress [accessed 2021-08-25]

50. Brooks SK, Webster RK, Smith LE, Woodland L, Wessely S, Greenberg N, et al. The psychological impact of quarantine and how to reduce it: rapid review of the evidence. Lancet 2020 Mar 14;395(10227):912-920 [FREE Full text] [doi: 10.1016/S0140-6736(20)30460-8] [Medline: 32112714]

51. Torres SJ, Nowson CA. Relationship between stress, eating behavior, and obesity. Nutrition 2007;23(11-12):887-894. [doi: 10.1016/j.nut.2007.08.008] [Medline: 17869482]

52. Yau YHC, Potenza MN. Stress and eating behaviors. Minerva Endocrinol 2013 Sep;38(3):255-267 [FREE Full text] [Medline: 24126546]

53. Moynihan AB, van Tilburg WAP, Igou ER, Wisman A, Donnelly AE, Mulcaire JB. Eaten up by boredom: consuming food to escape awareness of the bored self. Front Psychol 2015 Apr 01;6:369 [FREE Full text] [doi: 10.3389/fpsyg.2015.00369] [Medline: 25883579]

54. Deschasaux-Tanguy M, Druesne-Pecollo N, Esseddik Y, de Edelenyi FS, Alles B, Andreeva VA, et al. Diet and physical activity during the COVID-19 lockdown period (March-May 2020): results from the French NutriNet-Santé cohort study. medRxiv. Preprint posted online on June 5, 2020 [FREE Full text] [doi: 10.1101/2020.06.04.20121855]

55. Mattioli AV, Sciomer S, Cocchi C, Maffei S, Gallina S. Quarantine during COVID-19 outbreak: Changes in diet and physical activity increase the risk of cardiovascular disease. Nutr Metab Cardiovasc Dis 2020 Aug 28;30(9):1409-1417 [FREE Full text] [doi: 10.1016/j.numecd.2020.05.020] [Medline: 32571612]

56. Wiklund P. The role of physical activity and exercise in obesity and weight management: Time for critical appraisal. J Sport Health Sci 2016 Jun;5(2):151-154 [FREE Full text] [doi: 10.1016/j.jshs.2016.04.001] [Medline: 30356545]

57. Jiang Y. Problematic social media usage and anxiety among university students during the COVID-19 pandemic: The mediating role of psychological capital and the moderating role of academic burnout. Front Psychol 2021 Feb 05;12:612007 [FREE Full text] [doi: 10.3389/fpsyg.2021.612007] [Medline: 33613391]

58. Samet A. How the coronavirus is changing US social media usage. Insider Intelligence. 2020 Jul 29. URL: https://www. emarketer.com/content/how-coronavirus-changing-us-social-media-usage [accessed 2021-08-10]

59. Webb JB, Vinoski ER, Bonar AS, Davies AE, Etzel L. Fat is fashionable and fit: A comparative content analysis of Fatspiration and Health at Every Size Instagram images. Body Image 2017 Sep;22:53-64. [doi: 10.1016/j.bodyim.2017.05.003] [Medline: $\underline{28624756}$ ] 


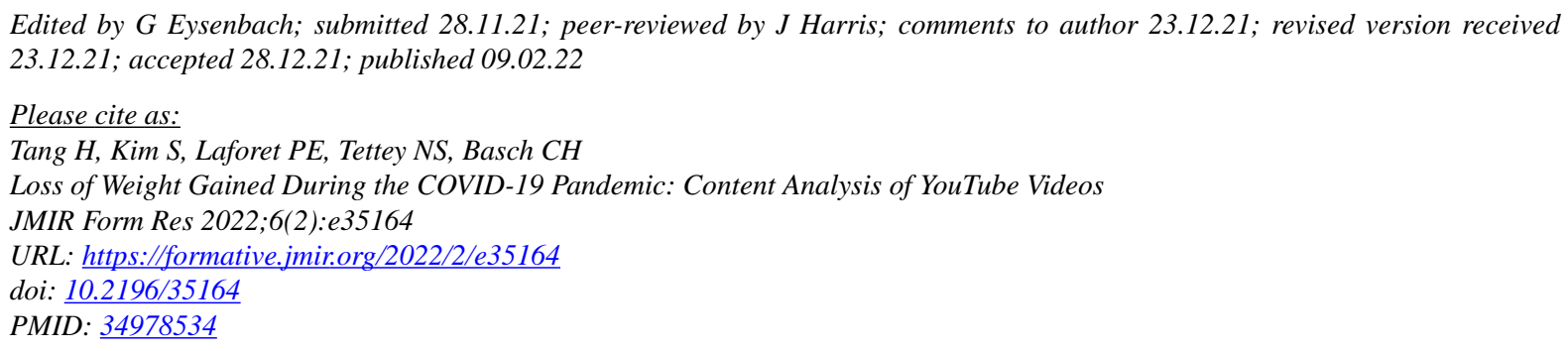

CHao Tang, Sungwoo Kim, Priscila E Laforet, Naa-Solo Tettey, Corey H Basch. Originally published in JMIR Formative Research (https://formative.jmir.org), 09.02.2022. This is an open-access article distributed under the terms of the Creative Commons Attribution License (https://creativecommons.org/licenses/by/4.0/), which permits unrestricted use, distribution, and reproduction in any medium, provided the original work, first published in JMIR Formative Research, is properly cited. The complete bibliographic information, a link to the original publication on https://formative.jmir.org, as well as this copyright and license information must be included. 